\title{
A qualified reading of the impact of tourism on island areas: the role of local populations in visits to tourist locations and perception of their environmental quality
}

\author{
C. Blondy, L. Vacher \& D. Vye \\ Agîle team, UMR 7266 LIENSS (Coastline, Environment and, Societies), \\ University of La Rochelle, France
}

\begin{abstract}
Island tourism is often studied through the prism of the negative impact on the environment and island societies, so creating a divide between tourists and local societies. Although there is no question that tourism has consequences for the environment, generally speaking, it is developing in regions which value environmental quality. This is particularly true of the Île de Ré, a symbolic place for tourism in France. However, the environment crystallises tensions evident in the discourses coming from the various players in this territory. As on other islands, the Ré beaches enjoy a favoured position within the tourism system, being central to tourist practices, particularly during the summer season. It is therefore our intention to qualify the impact of tourism on island areas through the example of visitors to the Île de Ré beaches. This study is founded on data from the Tourism and Leisure Practices Observatory. Analysis of the profiles and practices of those using the Ré beaches demonstrates the need to qualify the impact on the environment. Moreover, tourists are not alone in impacting on the environment. Cross-analysis of visitor numbers and factors influencing the choice of beaches reveals that visits are recurrent and regular since the beaches are perceived as being of high quality and in proximity to the place of residence of friends or family. Thus, the divide created between tourists and local society is brought into question since the latter, generally behind claims of excessive visitor numbers, helps to boost flows by welcoming friends and family.

Keywords: tourism, island, impact, environmental quality, beach, visitor numbers, practices, perception, local society.
\end{abstract}




\section{Introduction}

Island tourism is often studied through the prism of the negative impact on those territories where it is present, with particular criticism of its effects on island societies, environments and economies (Carlsen and Butler [1]). Tourism is often accused of fostering development of urbanisation and causing regions to be concreted over (Miossec [2]), putting pressure on water resources, creating traffic congestion and expanding to the detriment of traditional activities (fishing, farming, etc.), not to mention causing island economies to be more dependent on an activity tied to external factors while also undermining the traditional cultures and lifestyles of local societies. This approach spotlights the clash between "tourists" and "local societies" (Pizam [3]; Butler [4]; Michaud [5], Rossel [6]; Cazes [7, 8]; Péron [9]), almost placing the latter in a position where tourism is something they suffer from or have to endure. Although there is no question that tourism has harmful consequences for the environment (pressure on water, waste, etc.), generally speaking, it is developing in regions which value environmental quality, so indirectly contributing to its protection. Indeed, environmental quality is a selling point for tourism on island territories and is central to public policies for the planning and development of tourism islands (Duvat [10-12]).

The Île de Ré, a "symbolic place" for tourism in France, is structuring its appeal around an image of environmental quality (Péron [9]; Barthon [13, 14]). However, the environment crystallises conflicts and tensions evident in the discourses developed by the various players in this territory (Barthon [13]). As on other islands, the Île de Ré beaches enjoy a favoured position within the tourism system and actively participate in methods of recreation favoured by individuals, at least through rest (relaxing on the beach, sunbathing, etc.), leisure (bathing, beach volley, water sports, etc.), discovery (observing the coastal ecosystem) (MIT [15]), but also sociability like partying and meeting other beachgoers, etc. (Sacareau and Vacher [16]). Île de Ré beaches are therefore central to tourist practices, particularly during the summer season.

By means of this presentation, we aim to identify whether scientific analysis makes it possible to go beyond the perceptions of players with regard to tourism's impact. We will therefore ask whether analysis of visits to Île de Ré beaches allows some qualification of the discourses highlighting the negative impact of tourism on the island environment? This study is founded on data from the Tourism and Leisure Practices Observatory (LIENSs-University of La Rochelle) generated by surveys conducted as of 2008 .

After presenting the methodology and zone under study, we will demonstrate that analysis of the profiles and practices of those using the Île de Ré beaches allows the negative effects of tourists on the island environment to be qualified. We will subsequently highlight the contradictory nature of the discourse on island tourism before concluding with a description of the key management challenges arising from the relationship between tourism and the island environment. 


\section{Presentation of the zone and methodology: a qualitative approach to 'beachgoers' practices and discourses in a renowned Atlantic tourism island}

On the southern French Atlantic coastlines, mainland and island beaches are often central to recreational and tourism practices. It therefore appears of some value to focus on visits to beaches and the tourism practices present in order to reflect on the impact of tourism on island zones. Our study therefore focused on the case of the Île de Ré which is of interest for a number of reasons.

\subsection{The Île de Ré, a somewhat paradoxical "symbolic place" for Atlantic island tourism}

The Île de Ré is an island off the French Atlantic coast with 17,915 inhabitants according to the 2008 census. It lies a short distance from La Rochelle, a major tourist city which boasts relatively efficient transport connections thanks to a high-speed rail service to Paris and an expressway linking it with the A10 motorway, not to mention its airport.

Together with the Île de Noirmoutier and the Île d'Oléron, this island is fairly distinct and even paradoxical on the scale of the French Atlantic coast. In climatic terms, along with Oléron and Noirmoutier it is different from other Ponant islands due to a southern ocean climate which is milder (average annual temperature of around $\left.13^{\circ} \mathrm{C}\right)$, drier $(700 \mathrm{~mm} / \mathrm{p}$.a. for an average of 180 days of annual rainfall) and sunnier (2,200hrs/p.a.) (Barthon [14]). It is therefore an attractive island for beachgoers. Like Oléron (1966) and Noirmoutier (1971), its singular nature also stems from the territorial continuity achieved by the construction of a bridge between the mainland and Ré in 1988. Unlike the other two islands, the bridge has a toll which can establish a kind of economic and symbolic divide. It is worth noting that the Île de Ré is the only French island with a bridge connection to a major tourist city, La Rochelle.

Ré underwent development later than the rest of the Charentais coastline. Initially, its island status hampered the spread of tourism before becoming a springboard for its success, especially during Les Trentes Glorieuses (the postwar boom between 1945 and 1975) (Barthon [13]). From the late 19th century through to 1914, tourism on the Île de Ré was restricted to a scattering of visiting intellectuals or worthies. The opening of the Île de Ré bridge represented "confirmation of the island's tourism vocation" (Barthon [14]: 152). It is now a tourist location benefiting from a strong image and may be considered as a "symbolic place" for tourism in France. Not only has it served as the backdrop for cinema and TV films, but it has also inspired many painters and is a favourite location for figures from France's political, cultural and artistic spheres who have effectively brought Ré into the limelight.

Summer visitor numbers have risen steadily since the $1950 \mathrm{~s}$, jumping from 40,900 in 1957 , to just under 50,000 in 1968, over 110,000 in 1990 and around 140,000 today (Barthon [14]; Guérineau [17]). According to the Atlas of visitor numbers on Charente-Maritime beaches (Vacher et al. [18]), produced on the 
basis of aerial headcounts, on a "typical day" in August 2010, over 20,400 beachgoers flocked to Île de Ré beaches between $3 \mathrm{pm}$ and $5 \mathrm{pm}$ (figure 1).

In 2009, in terms of tourist infrastructures, the accommodation offer consisted in over 40,400 places of which $64 \%$ on campsites, some way ahead of graded furnished accommodation (18\%) and graded hotels $(6 \%)$. Tourism is a major economic activity on the island, creating over 3,200 jobs.

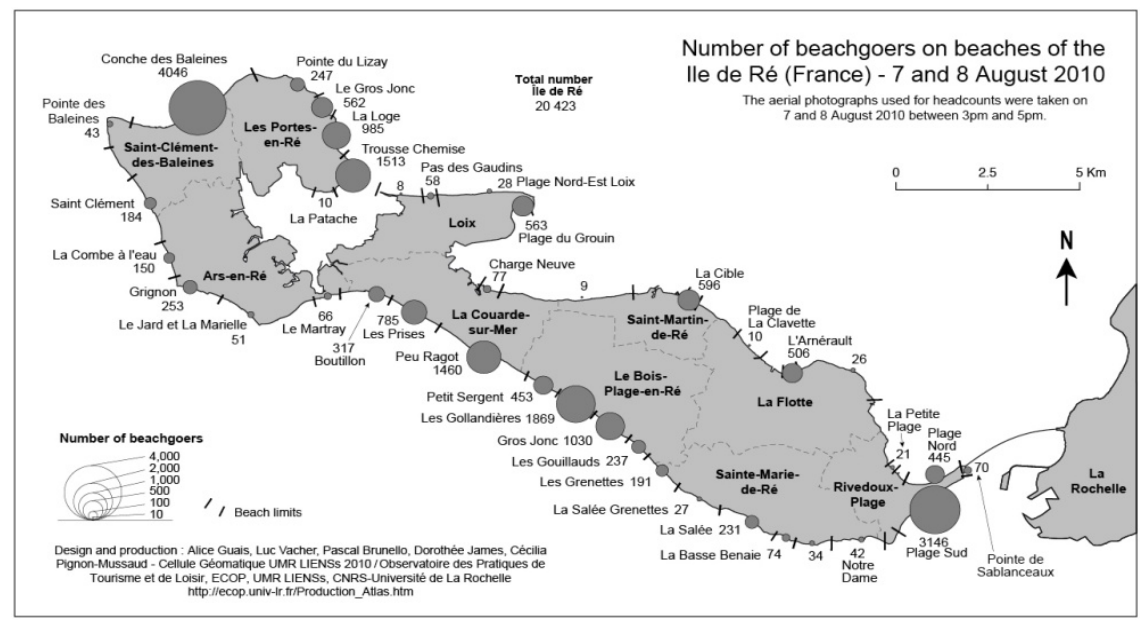

Figure 1: $\quad$ Number of beachgoers on beaches of the Île de Ré (France) on 7 and 8 August 2010. (Source: Tourism and Leisure Practices Observatory, aerial headcount in August 2010. ECOP/CNRS. University of La Rochelle.)

The island is therefore highly touristic but it nonetheless remains well protected on both the environmental and landscape levels. Environmental quality lies at the heart of public policies when it comes to management and development of the island territory. In 2010, almost $80 \%$ of zones were considered as natural or agricultural by the island's general plan in the shape of the SCOT (territorial coherence scheme). This stems from the key role of protected zones (Natura 2000, RAMSAR, the Conservatoire du littoral or coastline conservation authority, major bird protection zones, etc.). Moreover, in landscape terms, there are numerous construction and renovation regulations given the prevalence of "listed" or "heritage" sites on the territory. Many of these environmental measures were adopted at the time of the bridge's construction as if in anticipation of the impact of greater visitor numbers favoured by improved accessibility.

\subsection{An approach based on analysis of visits to beaches and the practices of beachgoers}

Beaches are major places for recreational and tourism practices on the Île de Ré territory. An often extensive sandy foreshore, the mild and sunny climate and/or 
the favourable sailing conditions make them suitable for a variety of practices: bathing, sunbathing, walks, shellfish gathering, surfing, kite surfing and wind surfing, etc. (ECOP survey, Guais et al. [19]). However, the Île de Ré beaches have very different profiles (wild or "urban") not to mention highly variable landscapes. We chose to conduct our study on a number of the most popular beaches (figure 1).

For our study, we focused on one beach in an urban context (Rivedoux Plage Sud), two beaches in a tourist context (Gros-Joncs and Gollandières at the BoisPlage-en-Ré), and a wild beach (Trousse-Chemise) (figure 2).

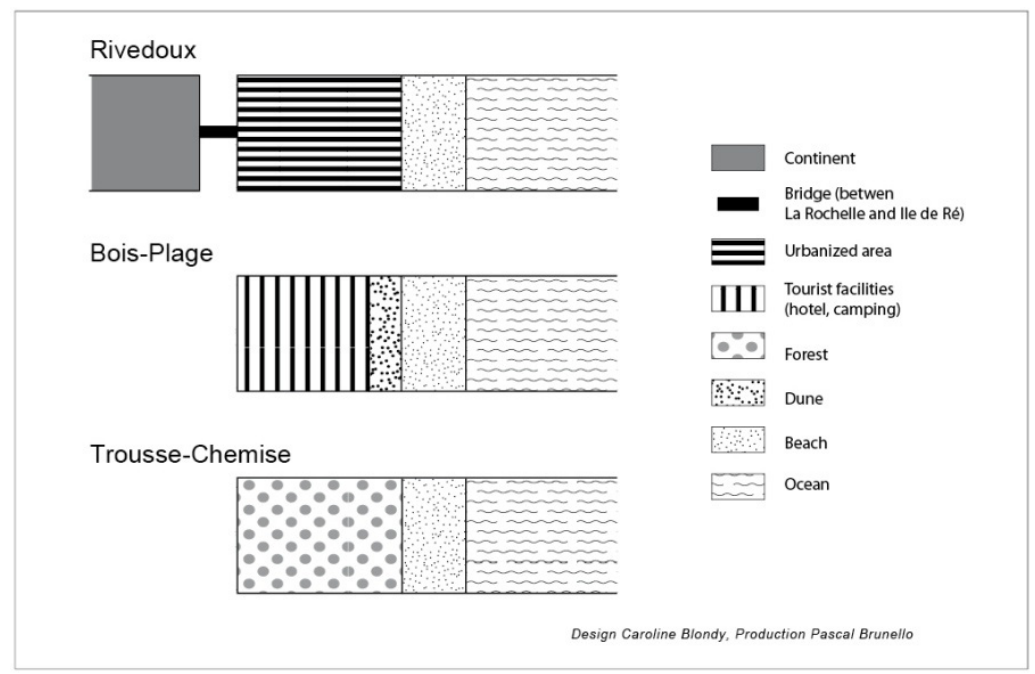

Figure 2: Three beaches surveyed, three different profiles. Design: C. Blondy; Production: Pascal Brunello, 2012.

The Trousse-Chemise beach on the north-west tip of the island, made famous by a Charles Aznavour song in 1962 and visits by members of the French jet set, is deemed a wild, sandy beach in the heart of a municipal area hosting a forest and a majority of secondary residences (most often owned by Parisians). A distinction was drawn between the two Bois-Plage beaches since beachgoers view them as separate with differing types of access. They can be seen as tourist beaches to the extent that a high concentration of campsites and other tourist infrastructures lies behind them. These are sandy beaches where dunes have been protected to prevent trampling with marked out access routes. Finally, Rivedoux Plage Sud finds itself in a semi-urban context. The opening of the Île de Ré bridge established a strong link between the mainland and the island, fostering semi-urbanisation of the eastern part of the island and the development of pendulum movements between Ré and La Rochelle. Located near the bridge, easily accessible throughout the year thanks to a bus service connecting all Île de Ré villages and a special city bus line to La Rochelle, it might be described as a "semi-urban" beach within the La Rochelle conurbation. 
These beaches were studied as part of surveys conducted for the ECOP (changes in coastlines and practices) observatory within the LIENSs (Coastline, Environment and Societies - UMR 7266) laboratory and the FREDD (federation of environmental research for sustainable development - FR 3097) at the University of La Rochelle. One of the key challenges for the ECOP observatory is gathering detailed data over a long period in respect of recreational and tourist use of the coastline thanks to one of its components, the Tourism and Leisure Practices Observatory created in 2007. The value of these data is two-fold. For researchers, they enable understanding of the practices and their related trends and for local politicians and administrators, they aid decision-making in respect of policies concerning development, management of the coastline and urban areas, and protection of the environment.

The observatory has been conducting summer survey campaigns on "Visitor numbers on Charente-Maritime beaches" since 2008. In this article, we will call on 2,400 questionnaires collected during the 2010 survey campaign of which 756 on the Île de Ré between 17 July and 28 August 2010.

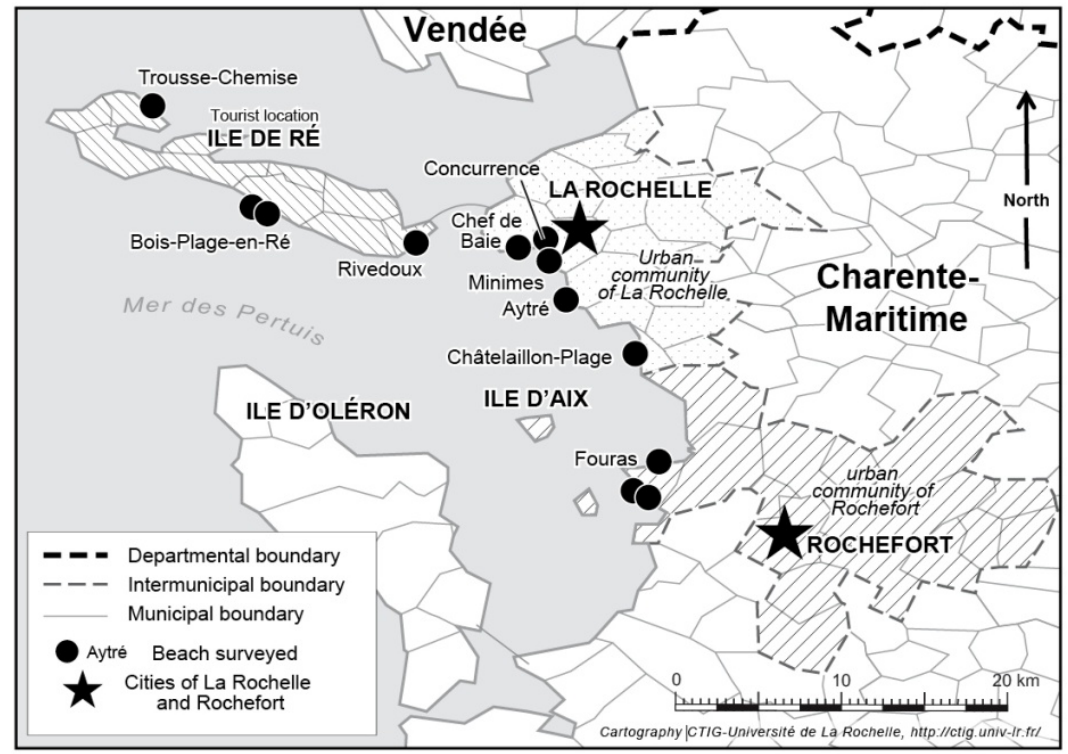

Figure 3: Map showing locations of beaches surveyed on the Charentais coast in the context of the ECOP survey. (Source: Vacher, Vye, 2012.)

The survey entailed in situ questioning of those using mainland and island beaches on the Charentais coast (figure 3). This will allow us to examine the specific features of island beaches in relation to mainland counterparts in terms of visitor numbers and practices.

These surveys were based on a qualitative and quantitative approach. The questionnaires made it possible to highlight the profile of users of the various 
beaches by considering their status in the location (tourist, day-tripper, secondary or principal residents, etc.), their perceptions of the environment and its quality, their type of accommodation and transport, their familiarity with the location as well as their practices on the beaches, etc. All of the data gathered during this campaign will be referenced in this article under the indication of "ECOP survey".

Our analysis is also founded on the report by Barbara Guérineau, Analysis of visitor numbers and practices on Ile de Ré for enhanced management of the territory, drafted in 2010 further to a commission from the Community of Communes of Île de Ré, in partnership with the University of La Rochelle. This study was conducted in the context of drafting of the SCOT (territorial coherence scheme) urban planning document. It was analysed on the basis of surveys conducted among 509 people on the Île de Ré between April and August 2010. This work was aimed at achieving a quantitative evaluation of visitor numbers on the island and their seasonal variations while also obtaining a qualitative picture of the leisure practices of populations present on the island and assessing the impacts thereof, particularly on the environment. We will refer to the data in this report under the indication of "CDC study".

\section{Tourists are not alone in impacting the island environment}

What is the real impact of tourists on the environment of an island as touristic as Ré? We will demonstrate that this impact should be qualified, to the extent that Ré beaches are not only used by tourists while those tourists present would seem to adopt behaviour which only has a minimal impact on the environment.

\subsection{Not all beachgoers are tourists}

In our study, we have identified several categories of users of the island's beaches. The main distinguishing criterion relates to the residence (principal, secondary, tourist accommodation). In fact, the type of residence determines a different relationship with the location (Vacher and Vye [20]) and tourists also have a temporary dwelling in tourist locations. Moreover, this type of tourist accommodation can also impact the relationship with the location: do tourists using pay-for accommodation (campsite, hotels) have the same kind of relationship with the location as those staying with friends or family? In addition to distinguishing criteria related to "residence", there is also the fact of staying at the tourist location or being a "day-tripper", in other words, visiting just for the day. It is therefore possible to identify eight different categories which are present to varying degrees depending on whether we are concerned with mainland or island beaches (figure 4). This shows that visits to a tourist location do not only concern tourists coexisting with people who live there all year round (referred to herein as principal residents) and who make up the core of the local population. 

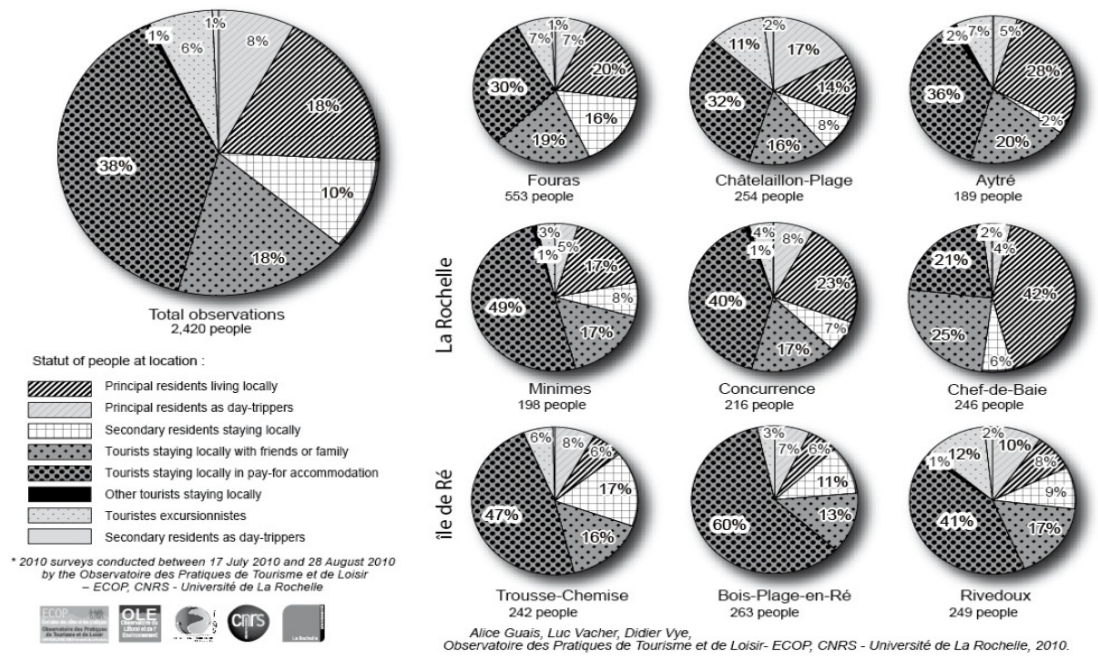

Figure 4: Status of people present on a selection of Charente-Maritime beaches during summer 2010. Source: ECOP survey, 2010.

On the Île de Ré beaches, at the height of the summer season, "tourists" as such, whether they are staying in pay-for accommodation or with friends or family, are very much in the majority as one might expect: $59 \%$ at Rivedoux, $63 \%$ at Trousse-Chemise and $73 \%$ at Bois-Plage. However, they are not the only ones present. In fact, beaches also host a significant number of day-trippers: $10 \%$ at Bois Plage, $16 \%$ at Trousse-Chemise and up to $24 \%$ at Rivedoux, the beach which is closest to the mainland. This proportion is consistently greater than that of mainland beaches (with the exception of Châtelaillon). Moreover, visitors to Île de Ré beaches also include secondary residents ( $9 \%$ to $17 \%$ depending on the beach with an East/West gradient), a hybrid category, being neither truly tourists nor truly residents (Urbain [21]; Sacareau et al. [22]). In fact, as on other tourist islands, the housing base is primarily comprised of secondary residences $(53.4 \%$ - source: DGI - French tax authority, 2007). These also welcome numerous tourists who stay with friends or family. As a result, there are more secondary residents on beaches than principal residents. Ultimately, the latter represent a small proportion of beachgoers compared to mainland beaches (between 6 and $8 \%$ by beach in 2010 compared to at least $14 \%$ on the mainland). This is primarily due to the low number of permanent inhabitants on Ré: just under 18,000 compared to 146,000 in the La Rochelle conurbation. Moreover, unlike Île de Ré, certain beaches attract large numbers of locals such as Chef-de-Baie.

Since beachgoers are not exclusively tourists, it is difficult to blame tourists alone for the impact of visits to beaches. This requires a qualified interpretation of the impact of tourism on the island area and analysis of beachgoers' practices will support this notion. 


\subsection{Practices impacting the environment differently depending on the status of the location}

It is possible to distinguish different types of behaviour in terms of practices according to the status of beachgoers in the locations. We have characterised a number of those liable to alter the environmental quality of the site:

- modes of transport on the island and the beaches (use of car, for instance)

- types of movement on and behind the beach (trampling of dunes)

- foreshore practices liable to modify ecosystems (shellfish gathering);

- practices on the beach liable to pollute the environment (picnics).

\subsection{1 "Soft" transport modes favoured by tourists}

In respect of transport for whatever purpose on the island scale, according to the CDC study, the car is the main transport mode for $59 \%$ of permanent residents surveyed whereas $52.8 \%$ of secondary residents prefer to cycle. This important role for the bicycle is partly due to an ambitious transport policy favoured by the Île de Ré municipalities which have turned the flat terrain to full account by creating a dense network of cycle paths (over $100 \mathrm{kms}$ of paths i.e. more than the road network). In any case, this environmental quality policy seems to have won over more secondary residents than permanent ones. Naturally, this could be due to the fact that, for the latter, Île de Ré is a place to live and work and the car remains an essential means of transport whereas it is a relaxation and leisure zone for the former population (Guérineau [17]). This difference in daily habits favours the adoption of different types of behaviour.

If we focus solely on journeys to the island's beaches, a similar logic emerges (figure 5). For permanent residents, the car remains the most popular transport mode $(56 \%)$ towards the island's two most central beaches (Gollandières and Gros-Jonc). Secondary residents only use the car in 39\% of cases, preferring "soft" modes instead. Finally, only 1 tourist in 4 (secondary residents excluded) uses the car, also preferring to reach the beach by bicycle $(38 \%)$ or on foot $(38 \%)$. The proximity of numerous campsites behind the dunes helps explain this decision. In fact, the ECOP surveys show that the key factor in choosing a beach when on holiday is the proximity, with the exception of the Trousse-Chemise beach, which is remote but renowned. However, the vast majority of day-trippers from the mainland, primarily residents of La Rochelle, prefer the car (94\%), as one might expect. This highlights the relative ineffectiveness of numerous policies favouring public transport and/or "soft" modes: the higher price of the bridge toll in summer, two bus companies running services to Île de Ré from La Rochelle, the free toll for cyclists who are able to board certain buses with their bicycles, etc.

Use of "soft" transport modes seems to be specific to the island to the extent that far more users drive to the beach on the mainland for the vast majority of beaches surveyed, whatever the type: beaches in a tourist context (Châtelaillon with $62 \%$ of users driving there) and urban beaches ( $49 \%$ of beachgoers came by car at Les Minimes, $80 \%$ at Chef de Baie). 


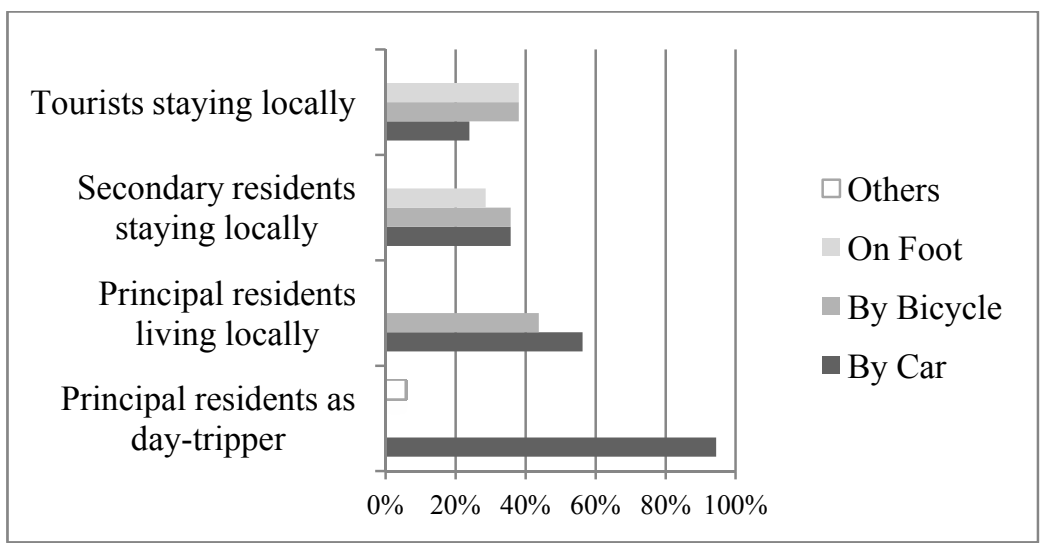

Figure 5: Transport modes to the beach according to status in the tourist location (Beaches of Bois-Plage-en-Ré, summer 2010). (Source: ECOP survey, 2010.)

\subsubsection{Practices on the beach which do not allow a distinction to be drawn between tourists and locals}

Concerning other practices liable to impact on the environment, the CDC survey shows that shellfish gathering, which is extremely popular on the Charentais coast, appears to be a minority pursuit among tourists, with just $15 \%$ practising it. This trend is confirmed by the ECOP surveys: $8 \%$ of tourists said they had taken part in this activity in the 7 days preceding the survey i.e. a figure slightly below that for principal residents $(10 \%)$.

Moreover, the proportion of permanent residents taking part in a water sport such as sailing and using a motor boat $(26 \%$ - source: CDC study, Guérineau [17]) is very similar to that for tourists $(23 \%$ - source: CDC study, Guérineau [17]). Picnicking on the beach or in a forest is, as one might expect, mostly favoured by day-trippers: 20\% picnicked during summer 2010 compared with $8 \%$ of tourists staying on the island and $10 \%$ of principal residents. In addition, tourists are often accused of causing dune erosion by trampling when out strolling or reaching a destination on foot. Yet, 89\% of tourists surveyed (CDC study, Guérineau [17]) said they walked on the beach without crossing the dunes. This finding qualifies the cliché of tourists as a threat to the dune ecosystem.

To sum up, there is no noteworthy difference between tourists and locals concerning this type of practice. More broadly, we are therefore some way removed from the image of the destructive tourist who shows little respect for the surrounding natural environment.

\section{A contradictory discourse on island tourism}

In addition to practices, it is interesting to analyse the discourses coming from tourists, residents and day-trippers as regards the environmental quality of a 
tourist location such as Île de Ré in order to identify possible contradictions and divisions.

\section{1 Île de Ré is perceived as a tourist location boasting excellent environmental quality}

Île de Ré is clearly perceived as presenting a quality environment by those who visit the island.

\subsubsection{The perception of the island and its beaches}

According to the CDC study [17], two thirds of people surveyed (residents, tourists and day-trippers taken together) put the quality of the landscape and the environment at the top of amenities specific to Île de Ré, even ahead of its island character $(40 \%)$ and its beaches (35\%) (figure 6).

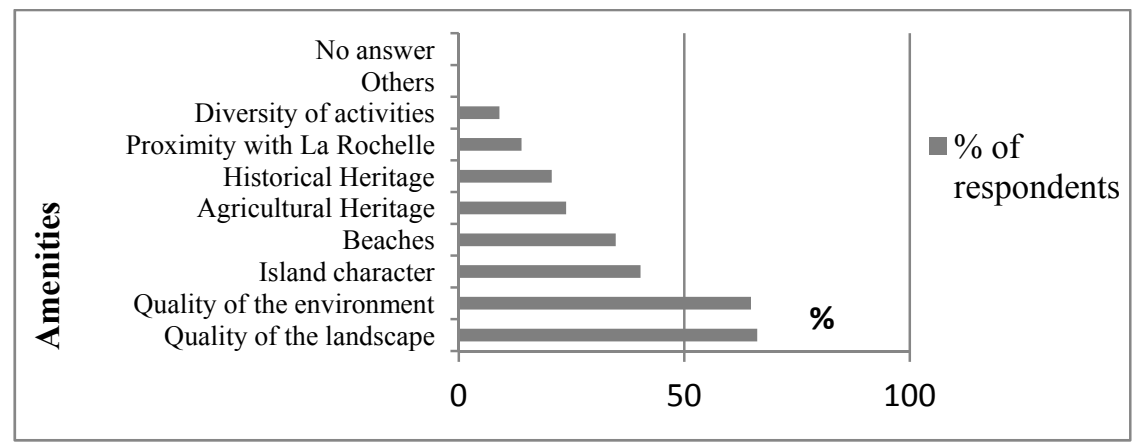

Figure 6: The principal amenities of Île de Ré according to surveys. Source: CDC study, 2010.

In the ECOP survey, non-permanent residents were asked which criteria attracted them to the island. Among these, the "natural beauty" criterion was mentioned by $20 \%$ of beachgoers at Trousse-Chemise or Bois-Plage i.e. the 2 nd or 3rd criteria, whereas it was a minority criterion on the mainland (mentioned by less than $10 \%$ of beachgoers). In fact, the wild and partly natural beach is a major factor of appeal for Ré compared to the artificial or semi-silted beaches of La Rochelle, Châtelaillon and Fouras.

\subsubsection{From the discourse to the reality: the regularity and history of visits}

Possible evidence of the persistence of the island's good environmental quality despite high visitor numbers resides in the fact that many of those visiting are clearly regulars who come back each year. According to the CDC study, almost 3 out of 4 tourists $(73 \%)$ had already visited the Île de Ré before $2010,45 \%$ visiting the island every year for at least 10 years and $25 \%$ of them having already spent their holidays there in the 1980s. These figures are confirmed by the ECOP survey, whereby $45.6 \%$ of respondents had been visiting the island's beaches for more than 10 years. Thus, a population which returns each year is a 
population whose appreciation of this tourist location is undiminished. According to the CDC survey, only $2 \%$ of tourists surveyed thought they would never return!

Moreover, depending on statuses in this location, although it is logical for principal residents or even secondary residents to have been visiting the island's beaches for longer ( $82 \%$ visiting the island for more than 10 years), there are almost as many tourists staying on the island who have been visiting the Ré beaches for more than 10 years $(36.5 \%$ vs. $39 \%)$ as tourists discovering Ré (1st visit in 2010). This is not the case for tourists visiting the city centre beaches in La Rochelle, with just $19 \%$ coming for more than 10 years whereas $60 \%$ only discovered them that summer (on their first visit to the city). This demonstrates the contrast between a tourist city where so called "repeater tourists" are in the minority and Île de Ré where the latter are as numerous as tourists visiting for the first time.

This regular nature of visits among tourists gives rise to better understanding of the environment which may translate into a better contribution to its protection ( $\mathrm{cf} 2.2 .2$ ).

\subsubsection{Perception of visits: a divide between local society and tourists?}

A large majority of those present on Ré beaches felt that there was "enough room on the beach", particularly at Trousse-Chemise. However, 28\% of respondents at Bois Plage said they were unhappy with the high density, due to the significant visitor numbers in the summer (figure 7). In the same way, people do not necessarily feel that "it would be better with fewer people" since this response is systematically a minority view including at Bois-Plage-en-Ré. The question of excessive visitor numbers does not therefore appear to be a major factor for users of beaches, irrespective of their status.

The CDC study raised the question of visitor numbers on the island scale: analysis of which is even more pertinent if we consider that density on the beach is minimal compared to other densities noted in island environments: only $5.8 \%$ of those surveyed in the CDC study felt that the density of beachgoers was a

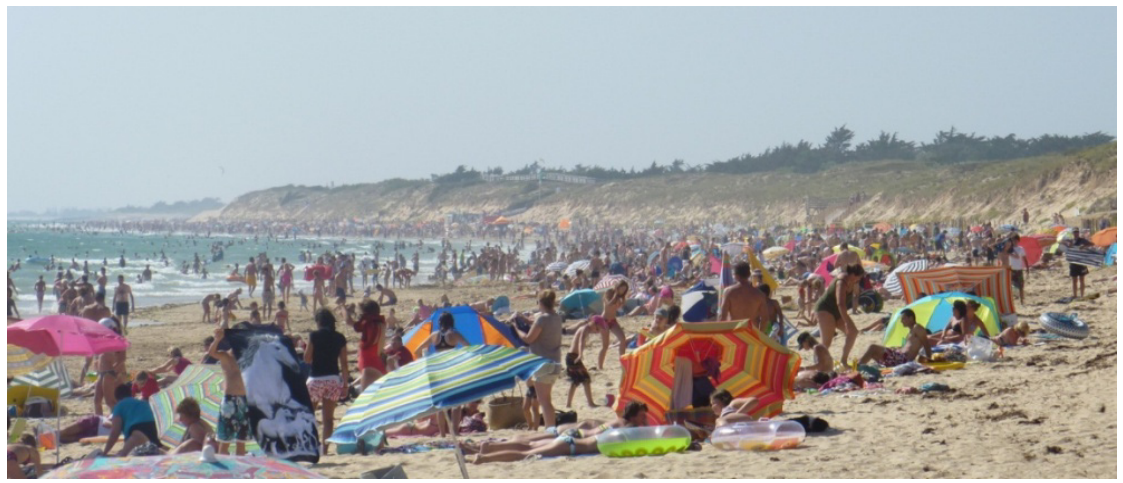

Figure 7: Beach at Bois-Plage-en-Ré on 27 July 2010 at $4.25 \mathrm{pm}$. (Source: ECOP report 2011 [19].) 
negative factor. In fact, $93 \%$ of tourists (excluding secondary residents and daytrippers) said they were not disturbed by the number of people on the territory during the summer season. This figure declines to $75 \%$ for secondary residents, which is still relatively high. However, only a narrow majority $(58 \%)$ of permanent residents were not disturbed by tourist numbers, demonstrating that this perception is more negative among island inhabitants. A finding borne out by the fact that the latter overestimate the number of people present on Ré in the summer: whereas the main studies of visitor numbers produce figures of between 135,000 and $145,000,35 \%$ of inhabitants estimate numbers to be over 150,000 on the island compared with just $18 \%$ of tourists. The main reasons for dissatisfaction are the lack of respect for others shown by "tourists" on cycle paths, the high number of cars on the road, whereas, as we have seen, tourists use this mode of transport less than other beachgoers proportionally speaking, and the density of visitors in villages. In addition, problems related to parking only represent $3.2 \%$ of reasons for dissatisfaction, which clearly goes against the notion of a space which is saturated, as often lamented in the local press (CDC study, Guérineau [17]).

It therefore seems that there is a divide between the island's inhabitants and tourists as to the perception of visitor numbers but it remains paradoxical since, as we will see, residents help to boost flows by welcoming numerous friends and family members for their holidays.

\subsection{The role of local society in "boosting" visitor numbers}

Although $42 \%$ of principal residents say that the significant visitor numbers in the high season is a negative factor, this does not translate into a summer exodus since $90 \%$ of them stay on the island during this period (CDC study, Guérineau [17]). This is partly due to the fact that some earn a living from tourism or because they accommodate friends and family. In fact, spending time with friends and family (whether permanent or secondary residents, friends or family) is the primary motivation for visiting Ré in the summer, ahead of certain criteria related to the landscape (beach, natural beauty): indeed $40 \%$ of beachgoers cite this as their reason for visiting the Île de Ré, whether to see family $(30 \%)$ or friends (10\%) (figure 7).

In addition, family or friends also play an important role when it comes to tourist accommodation in two main ways:

- $\quad$ either by advising tourists: $27 \%$ of tourists present at Trousse-Chemise and Rivedoux found their accommodation thanks to local residents (source: ECOP, Guais et al. [19]). This role played by friends or family is far greater on the Île de Ré than in mainland tourist locations where the Internet, the principal method used, is more popular, being used by at least $60 \%$ of tourists whereas the figure is below $50 \%$ on Île de Ré, irrespective of the beach.

- $\quad$ or by accommodating tourists directly. Although pay-for accommodation is the main category, the home of friends or family remains a significant alternative on Ré. Thus, secondary or principal residents accommodate 
around 1 tourist in 4 on Île de Ré in summer. This proportion is relatively low at Bois-Plage $(19 \%)$ due to the considerable presence of pay-for accommodation but represents almost one third of flows at TrousseChemise. Even if this phenomenon is not specific to the tourist island, 27\% of beachgoers on La Rochelle's urban beaches are in this situation, it offers us a timely reminder of the role played by permanent or secondary residents themselves when it comes to the number of tourists in a location.

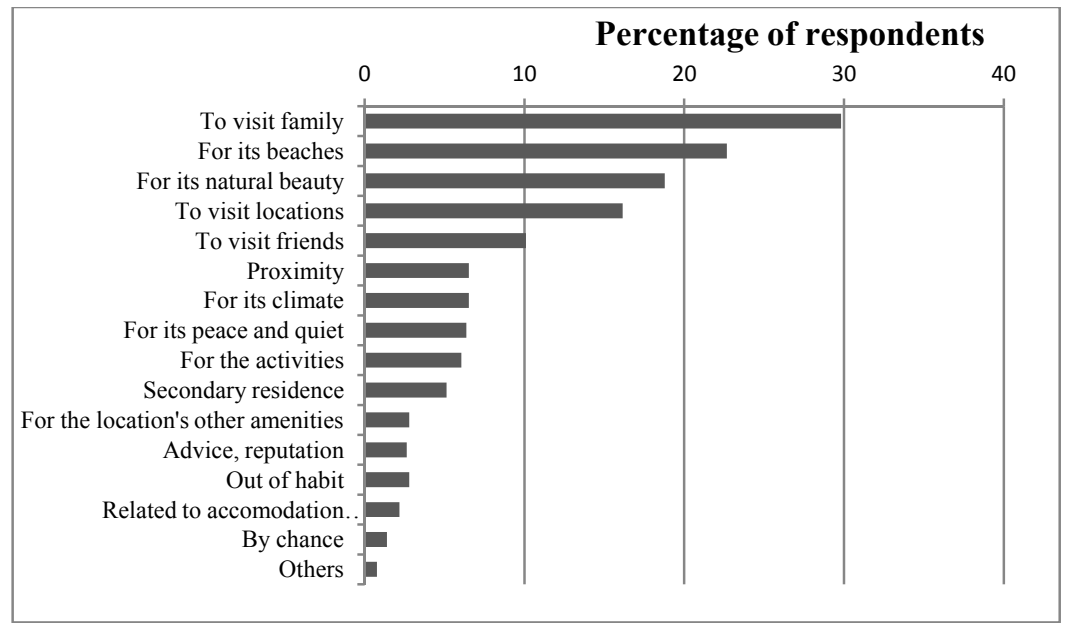

Figure 8: Reasons for visiting Île de Ré in summer. Source: ECOP survey, 2010. Percentage calculated out of 644 respondents (Several answers possible - principal residents excluded)

\section{Discussion/conclusion}

As for all human activities, tourism impacts the territory and societies in which it develops. However, the finger of accusation is generally pointed at individual tourists more than tourism itself (MIT [15]). The discourses are often highly paradoxical. Tourism is frequently mentioned as a factor of development for an island territory alongside anti-tourist discourses, as if it were possible to develop tourism without tourists (MIT [15]; Blondy [23]). In fact, tourists are often more numerous than island residents and therefore have a significant impact on the environment. There is a numbers effect which feeds into discourses on invasion and supports the notion of an island which is wilting under the strain of visitor numbers (Aristégui [24]; Brosset [25]). However, our study demonstrates that the local population may engage in practices which are very similar to those of tourists or which even have a bigger impact on the island environment (use of car, shellfish gathering, etc.). Therefore, although it does not call into question the effect of the number of tourists in cramped island spaces and within lowpopulation societies, our study does make it possible to reconsider not only the discourse condemning mass tourism and stigmatising tourists but also scientific 
approaches to tourism creating a divide between "tourists" and "locals", which consider these two categories to be often homogenous and distinct (Pizam [3]; Butler [4]; Michaud [5], Rossel [6]; Cazes [7] and [8]), whereas they are in fact heterogeneous and permeable (Blondy [23]). The study of tourism, understood as a "system of players, practices and locations" (MIT [26]: 287), incorporates the practices of the different players in the tourist locations and examines the links between them and the status of users in the location. This demonstrates the complexity and subtlety of the categories of "tourists" and "locals". In fact, secondary residents are therefore a category lying somewhere in between tourists and permanent residents. Similarly, day-trippers include both tourists staying off the island and mainland residents. This permeability is also permitted by the role of inhabitants and secondary residents who accommodate tourists (family or friends) and may introduce them to the location and show them around, so setting them apart from tourists who visit for the first time without any attachments to the location, i.e. so-called "novice" tourists (Blondy [27]). This permeability between categories is therefore evident in the statuses of the individuals in the location as well as the practices and the discourses. Locals sometimes engage in the same practices as the stigmatised tourists. It is therefore difficult to draw a contrast between them. As for the discourses, there exists a certain consensus between the different categories concerning the environmental quality of the Île de Ré. However, this has not forestalled a debate over aspects such as the bridge toll. Tourists and day-trippers would be delighted if the bridge were made free. Certain professionals on the Île de Ré (restaurateurs, hoteliers, shopkeepers, etc.) would appear to be favourable to waiving the toll for daytrippers, particularly during the off season in order to expand their clientele with the medium-sized city of La Rochelle then becoming a catchment area which could be mobilised more readily. Conversely, many secondary residents, but also some permanent ones, express opposition to a free bridge due to the risk of invasion and saturation of locations, while arguing in favour of protecting the environment. In fact, the toll, which became an ecotax in 2012, helps pay for the environmental protection policy thanks to the tourists and day-trippers arriving by car. Ultimately, we might ask whether environmental quality is not exploited by local players in two respects: deployed as an argument for attracting tourists, it is also paradoxically a means of exclusion, leading perhaps to a kind of cosy insularity shared by permanent and secondary residents who, by protecting environmental quality, are also protecting their property assets. Our study could be supplemented by review of environmental management of the territory. Bearing in mind that the local population is a vector for tourist flows, perhaps administrators should target it more effectively for better integration into their environmental awareness policy. Moreover, the significant presence of daytrippers demonstrates the limits of management organised on the scale of the island alone to the extent that policies, and in particular those relating to awareness, also concern the population bases from which day-trippers travel, especially when they are close by (La Rochelle/Île de Ré tandem). Rather than treating day-trippers as scapegoats, (Aristégui [24]; Brosset [25]), it would be preferable to investigate their place of origin and the way in which they might be 
integrated into an environmental awareness policy while also giving them the chance to visit locations differently by introducing a more convincing transport policy (public transport, "soft" modes, etc.) which is better tailored to the source population bases.

\section{References}

[1] Carlsen, J. and Butler, R., Island tourism: sustainable perspectives/edited by Jack Carlsen and Richard Butler CABI, Wallingford, Oxfordshire; Cambridge, MA, 249 p, 2011.

[2] Miossec, A., Les littoraux: Entre nature et aménagement, Sedes, Paris, 1997.

[3] Pizam, A., "Tourism's impacts: The social costs to the destination community as perceived by its residents", Journal of Travel Research, 16 (4), pp. 8-12, 1978.

[4] Butler R., "The social implications of Tourist Developments", Annals of Tourism Research, vol 2, n², pp. 100-110, novembre-décembre 1974.

[5] Michaud, J.-L., Le tourisme face à l'environnement, PUF, Paris, 1983.

[6] Rossel, P., Tourisme et Tiers-Monde: un mariage blanc, P.M. Fabre, Paris, 1984.

[7] Cazes G., Le tourisme international; mirage ou stratégie d'avenir?, Hatier Paris, 1989.

[8] Cazes G., Tourisme et Tiers-Monde. Un bilan controversé: les nouvelles colonies de vacances, tome 2, L'Harmattan, Paris, 1992.

[9] Péron F., "Fonctions sociales et dimensions subjectives des espaces insulaires (à partir de l'exemple des îles du Ponant)", Annales de géographie, Volume 114, n 644, pp. 422-436, 2005.

[10] Duvat, V., "La qualité des plages au cœur des enjeux de développement : La situation des îles de l'océan Indien", EchoGéo [En ligne], Numéro 7, 2008.

[11] Duvat, V., "Qualité des plages et tourisme dans les îles vierges britanniques", Études caribéennes [En ligne], Décembre 2009.

[12] Duvat, V., "La qualité des plages au cœur de la gestion intégrée des zones cotières: l'exemple du plan d'action Oléron qualité littoral (Côte atlantique française)", VertigO - la revue électronique en sciences de l'environnement [En ligne], hors-série 9, Juillet 2011.

[13] Barthon C., Géographie, culture et patrimoine: essai sur l'identité insulaire charentaise à partir des exemples des îles de Ré et d'Oléron, Thèse de doctorat, Université de Nantes, 388 pages, 2000.

[14] Barthon C., L'Ile de Ré, Editions Palatines, Paris, 238p, 2005.

[15] Equipe MIT, Tourisme 1, Lieux communs, Belin, Coll. Mappemonde, Paris, 320p, 2002.

[16] Sacareau I. and Vacher L., "Le tourisme en pratiques. La révolution permanente?" in Equipe MIT, Tourisme 3, La révolution durable, Belin, coll. Mappemonde, Paris, pp. 19-120, 2011.

[17] Guérineau B., Analyse de la fréquentation et des pratiques sur l'Ile de Ré pour une meilleure gestion du territoire, mémoire de Master 2 Sciences 
pour l'environnement, Université de La Rochelle, 115p, 2010, (CDC study, 2010).

[18] Vacher L. et alii, Atlas de la fréquentation des plages de CharenteMaritime, Campagne 2010, Observatoires des Pratiques de Tourisme et de Loisir-ECOP, Cellule Géomatique de l'UMR LIENSs, UMR 6250 LIttoral ENvironnement et Sociétés (LIENSs), CNRS - Université de La Rochelle, La Rochelle, 316 p, 2011.

[19] Guais A., Vacher L. and Vye D., Rapport Campagne d'enquêtes été 2010, Observatoire des Pratiques de Tourisme et de Loisir-ECOP, UMR LIENSs, CNRS - Université de La Rochelle, La Rochelle, 186 p, 2011, (ECOP survey, 2010).

[20] Vacher L. and Vye D., "Penser 1'habiter à partir de la pratique des lieux touristiques par les excursionnistes, touristes et résidents », In : Frelat-Kahn B., and Lazzarotti O., Habiter : vers un nouveau concept, Armand Colin, collection "Cursus" pp. 197-210, 2012.

[21] Urbain J.-D., "Le résident secondaire, un touriste à part?”, Ethnologie Française, vol.32, pp. 515-520, 2002.

[22] Sacareau I., Vacher L., Vye D., "La résidence secondaire est-elle un objet aux confins du tourisme? Réflexions à partir de l'exemple des résidences secondaires des Britanniques en Poitou-Charentes", In Bourdeau P., François H., Perrin-Bensahe L. (éd.), Fins et confins du tourisme, Paris, L'Harmattan, (à paraitre en 2012).

[23] Blondy C., Les territoires touristiques polynésiens, une lecture géographique de la participation de la société locale au système touristique, Thèse de doctorat, Université de Bordeaux III, 781p, 2010.

[24] Aristégui M.-C., "Sur le pont de l'île de Ré, on paye désormais une écotaxe", Sud-Ouest, [en ligne], 31/12/2011.

[25] Brosset T., "Parce qu'elle le vaut bien", Sud-Ouest, [en ligne], 01/12/2011.

[26] Equipe MIT, Le tourisme, acteurs, lieux et enjeux, Paris, Belin, Coll. Mappemonde, 299p, 2003.

[27] Blondy C., "Les touristes dans le système touristique polynésien: essai de typologie", Mappemonde, $\mathrm{n}^{\circ} 105,2012$.

[28] Berno T., "When a guest is a guest: Cook Islanders view tourism", Annals of Tourism Research, vol.26, Issue 3, July 1999. 